\title{
THE SORPTION OF WATER BY RUBBER (Part 1)
}

\section{SORPTION OF WATER BY GHLOROPRENE RUBBER COMPOUNDS}

S. Watanabe (Wire \& Cable Works, Hitachi Wire \& Cable Ltd.)

It has been reported that the sorption of water by vulcanized rubber is proportional to the surface area and varies as the square root of immersion time, and can not observe the saturated point experimentally. This is very interesting phenomenon, but there is little report which explain this sorption mechanism.

The author discovered that the rubber vulcanizates do not saturate in pure water, but saturate in salt water solution, and explained the sorption mechanism by thermodynamical treatment.

In this Part 1, the author reports the preliminary experiments which are observed by chloroprene rubber compounds, and the presumed osmotic mechanism theory of sorption.

IIItI)

\section{電解質含有量とゴムの吸水量の関係}

（昭和36年 1 月12日 受理）

\section{渡辺茂隆}

\begin{abstract}
要 旨 第1報に扔いて，クロロプレンゴムの浸水中に括ける吸水状態を测定し，ゴムの吸水が滲透压上ゴ 厶弾性力の拮抗作用に基づくことを推定したが，ゴム中の水溶性物質の定量が不可能のため，との機構を定 量的に解析することができなかった。このため本報では，一定量の電解質を配合したブチルゴム試料の一定 濃度食塩水中に抽ける吸水飽和值を奏測した結果をのべる，飽和吸水量は電解質含有量と食塩水濃度の函数 乙なる．また，各種合成ゴムの基嘫配合試料についても同様な吸水実験を行ない，前述の場合上同様に浸漬 溶液濃度に依存する飽和值に達するととを認めた。なお，吸水速度は温度によって变化するが，吸水飽和值 は温度によっではとんじ変化しない。
\end{abstract}

\section{1. 緒言}

第 1 報》において，クロロプレンゴムの浸水状態にお ける吸水量を実測し，ゴムの吸水が主ししてゴムの反撥 弾性力上水溶液滲透任之の拮抗作用によるもの上推定し たが，ゴム中の水溶性物質量の実測が不可能のため，こ の機構を定量的に確認することができなかった。

このため，本報に批いては，一定量の水溶性電解質を 配合したブチルゴム試料の，一定濃度食塩水中における 吸水状態を観測した結果を報告する。なお，各種の合成 ゴムの基礎配合加硫物についても同様実驗を行なった。

\section{2. 試料}

\section{1 電解質配合方法}

ゴム中に水溶性電解質を配合するこしは，一般に行な われていないので，ての配合方法が問題となる。まず,

+本報を〔ゴム加硫物の吸水現象比関する研究（第 2 報) とする。

*日立電線株式会社電線工場研究部
一般的な電解質として食塩 $(\mathrm{NaCl})$ を選び，充垻剂を配 合する場合と同様に固形のままロール混合した。乙の結 果は, $\mathrm{NaCl}$ がゴム中に均一に分散しないで, 直径 1〜 $0.5 \mathrm{~mm}$ の結晶粒となって残り, 満足な試料を調製する ことができなかった。なお，蕉糖も用いてみたが，食塩 と同様汇分散不良となり，またこの場合は加硫中江分解 し始め，一部炭化してくる。

しかし，適当な結晶水をもち，ロ一ル混合温度以下で 結晶水を放し，溶解状態亡なる金属塩は，ロール混合中 に波状となってゴム中に均一に分散することを見出し， てのような結晶水放出温度の低い金属塩を配合すること により，满足な電解質含有ゴム試料を調製できた。

なお，更に検討した結果，食㦈も濃水溶液としてゴム 中にロール混合し，完全に分散した 後にロール温度を $100^{\circ} \mathrm{C}$ 以上にあげて含有水分を除けば，充分満足し得る 試料を調製できるととを見出した。

\section{2 供試試料}

供試試料の配合表を表 1 亿示す。市なわち，ブチルゴ ム(Polymer Corp. 製：ポリサーブチル301）飞慣用さ 
れている加硫剂を即合して基礎配合しし，更に適当量の

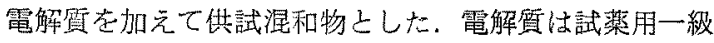
の $\mathrm{MgCl}_{2} 6 \mathrm{H}_{2} \mathrm{O}$ お上び $\mathrm{NaCl}$ を用い(再結晶一回), 前 者は結晶状のものをそのまま配合し, 後者は濃厚水溶液 として配合した。

試料片の調整は次のようにして行なった。ブチルゴム を約 $40^{\circ} \mathrm{C}$ のール温度で混合しながら， $\mathrm{MgCl}_{2} 6 \mathrm{H}_{2} \mathrm{O}$, あるいは $\mathrm{NaCl}$ 水溶腹を配合し，分散後にロール温度を $100 \sim 140^{\circ} \mathrm{C}$ にあげて約 20 分混練し，含有水分の大部分 を除く．更にこの試料老約 $0.5 \mathrm{~mm}$ の板状に延ばして五 酸化燐老共存させた真空高温乾燥器中に移し, $80^{\circ} \mathrm{C}, 2$ 時間の乾燥処理走行ない, その後, 常温の五酸化燐真空 デシケータ中に一昼夜以上放置した。

とのようにして得た電解質配合ブチルゴムに, 表 1 に 示す加硫剂を配合し，プレス加硫 $\left(150^{\circ} \mathrm{C} ， 30\right.$ 分)して 供試試料とした。試料片の厚さは $0.25 \pm 0.05 \mathrm{~mm}$ であ b，直径 $30 \mathrm{~mm}$ m円型に打ち抜いて供試した。

な执，電解留含有量は試料片の灭分測定加ら定量し た。すなわち，試料約 $5 \mathrm{~g}$ を坩绵に上り，約 $800^{\circ} \mathrm{C}$ で恒 量に趔するまで灼熱して灰分量を求め，同一条件で求め た基整配合（A試料）の灰分量に比べての増加量を電解 軼配合量乙した。この実測結果は表1に併記したが， $\mathrm{MgCl}_{2}$ の場合估，残存水分がある。，

$$
\begin{array}{ll}
\mathrm{MgCl}_{2}+\mathrm{H}_{2} \mathrm{O} \rightleftarrows \mathrm{Mg}(\mathrm{OH}) \mathrm{Cl}+\mathrm{HCl} & 350 \sim 505^{\circ} \mathrm{C} \\
\mathrm{MgCl}_{2}+\mathrm{H}_{2} \mathrm{O} \rightleftarrows \mathrm{MgO}+2 \mathrm{HCl} & 510^{\circ} \mathrm{C} \text { 以上 }
\end{array}
$$

のような反応がおこることが知られているので，灰分量 加战めた $\mathrm{MgCl}_{2}$ の量注愦差老生ず石可能性がある。

表 1 電解質配合ブチルゴム試料の配合表

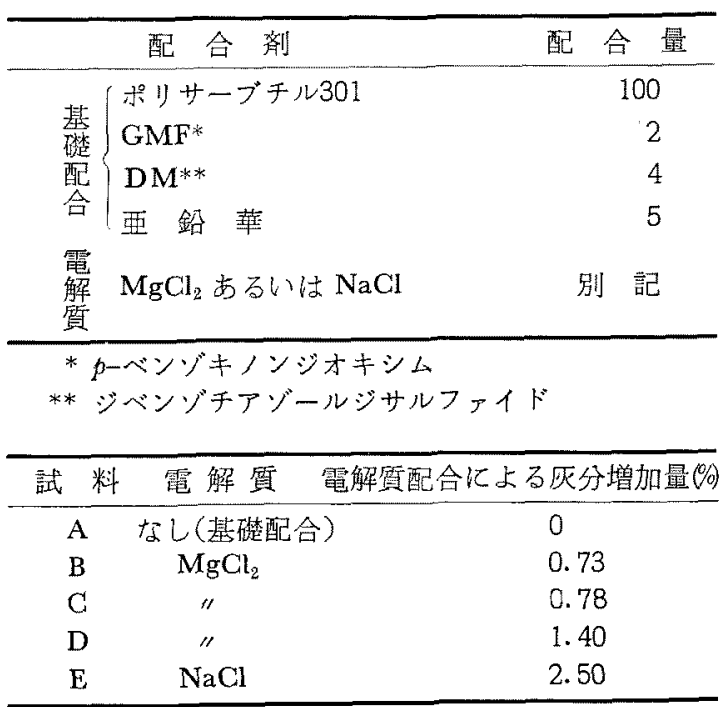

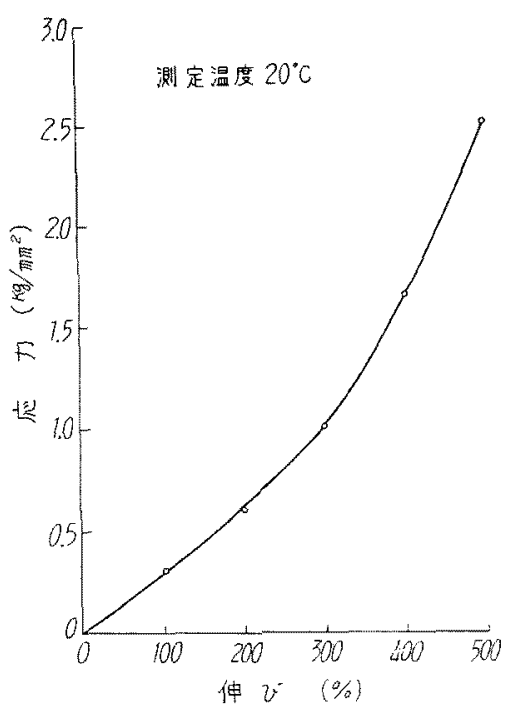

图 1 基憷配合ブチルゴムの応力歪曲線

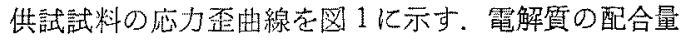
は少ないので, 各試料の応力歪曲線は重なり, 各試料の モジュラスは同等であると見なし得る。

\section{3 漫 婊夜}

浸漬液は蒸溜水，および試薬用一級 $\mathrm{NaCl}$ （再結晶： 1 回）を溶解した食塩水溶液を用いた。濃度は $m$ (モル) $\left.1 \mathrm{kgH}_{2} \mathrm{O}\right)$ 単位で示した。

\section{3. 実験}

吸水量の塞测方法は第 1 報の場合と同様に，試料片を 一定温度执よび一定浱度の水溶液中に浸漬し，一定期闑

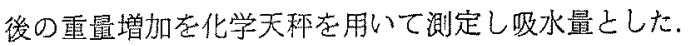

\section{1 電解質含有量と吸水}

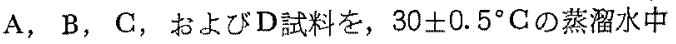
に浸瀆した場合の吸水状態を图 2 に示す

電解質含有量が増加すると吸水量も大きくなる。吸水 量は，第 1 報の測定結果之同様に，浸漬期間の平方根に

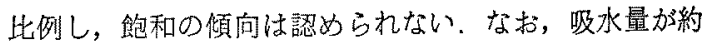
30\%以上になる上，ての規則性がくずれてより以上の吸 水を示方。

次に，A〜D試料を，0.504，1.017，および $4.347 m$ の食塩水中に浸漬した場合の吸水状態を图3〜6に示す.

食塩水濃度が濃くなる上共仅吸水量は減少し，蒸溜水 中では全く認められなかった飽和平衡值も認められるよ うになる。

ての実験から求めた飽和値を一括して表 2 亿示す，飽 和吸水量は $\mathrm{MgCl}_{2}$ 配合量の增大と共に大きくなり，ま 


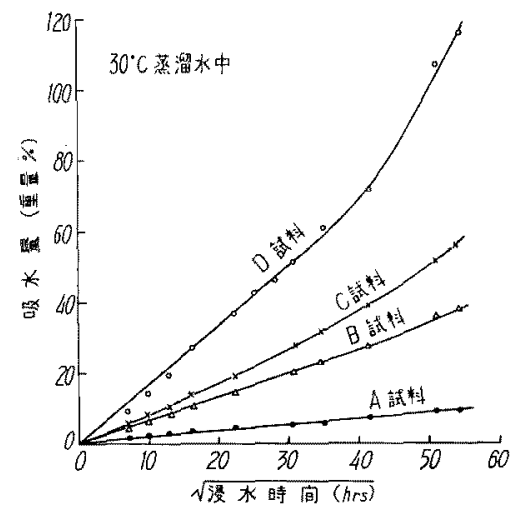

図 2 電解質含有量の異るゴム試料の吸水

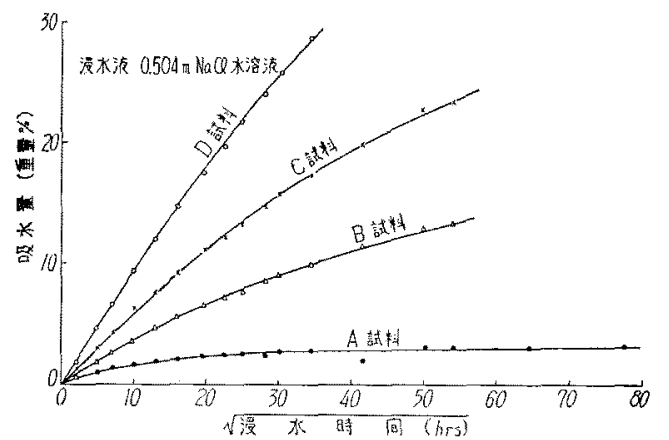

因 $3 \mathrm{MgCl}_{2}$ 配合ブチルゴムフ食塩水中に括ける吸水? ( 201$)$

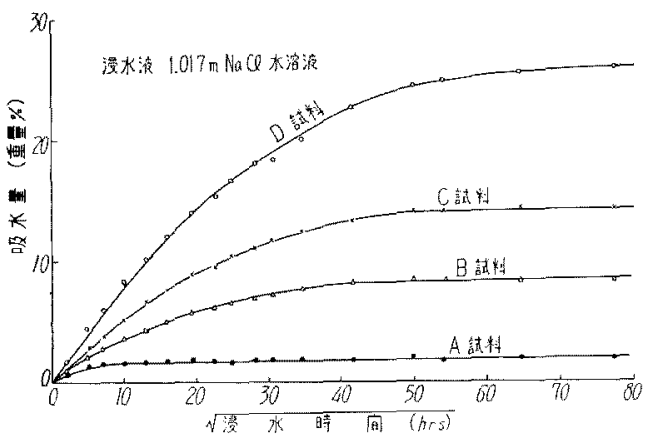

因 $4 \mathrm{MgCl}_{2}$ 配合ブチルゴムの食塩水 中に㕲ける吸水（その2）

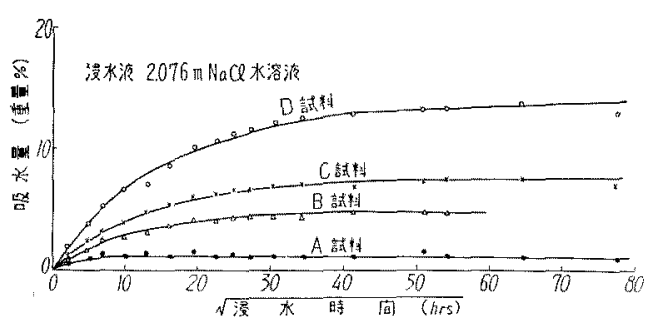

图 $5 \mathrm{MgCl}_{2}$ 配合ブチルゴムの食塩水 中におりる吸水（その3）

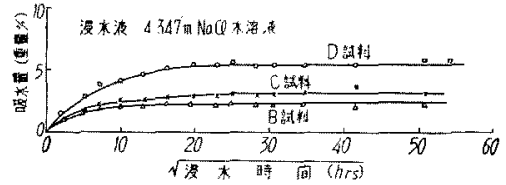

図 $6 \mathrm{MgCl}_{2}$ 配合ブチルゴムの食塩水 中に打りる吸水（その4）

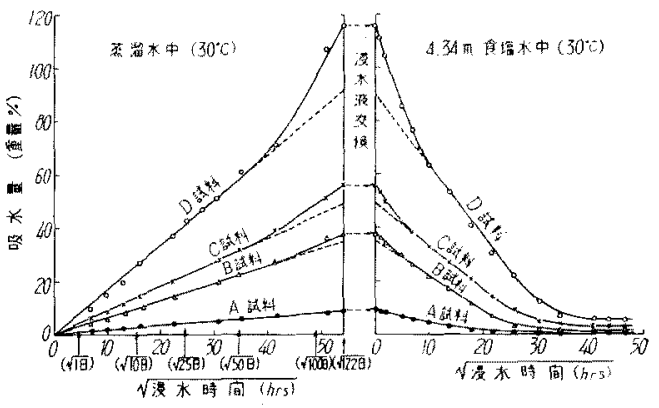

図 7 ブチルゴムの䒱溜水中にお的る 吸水及び食塩水中における脱水

表 2 飽和吸水量実測結果

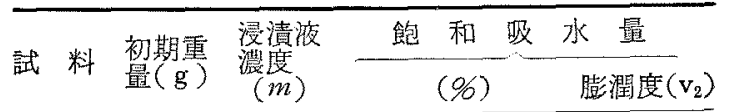

$\mathrm{A}\left\{\begin{array}{llcr}0.1162 & 0 & \text { (飽和の傾向なし) } & \text { - } \\ 0.1266 & 0.504 & 3.1 & 0.969 \\ 0.1039 & 1.017 & 1.9 & 0.981 \\ 0.1195 & 2.076 & 1.2 & 0.988\end{array}\right.$

0.10840 （飽和の傾向なし） -

B $\left\{\begin{array}{cccc}0.1384 & 0.504 & \text { (末飽和) } & \text { - } \\ 0.1229 & 1.017 & 8.4 & 0.921\end{array}\right.$

$\begin{array}{llll}0.1324 & 2.076 & 4.3 & 0.958\end{array}$

$\begin{array}{llll}0.1050 & 4.347 & 1.9 & 0.981\end{array}$

0.11360 （飽和の傾向なし） -

0.11550 .504 (未䭂和) -

C

$\begin{array}{rrrr}0.1077 & 1.017 & 14.1 & 0.874 \\ 0.1149 & 2.076 & 7.6 & 0.928 \\ 0.1269 & 4.347 & 3.1 & 0.969\end{array}$

0.11360 (飽和の傾向なし) -

0.12010 .504 (未飽和) -

D $\left\{\begin{array}{llll}0.1154 & 1.017 & 26.0 & 0.789\end{array}\right.$

$\begin{array}{llll}0.1139 & 2.076 & 14.0 & 0.874\end{array}$

$\begin{array}{llll}0.1291 & 4.347 & 5.9 & 0.943\end{array}$

$\begin{array}{llll}0.1671 & 2.0 & 16.3 & 0.880\end{array}$

$\begin{array}{llll}0.1956 & 2.5 & 13.0 & 0.888\end{array}$

$\begin{array}{llll}0.1514 & 3.0 & 12.0 & 0.905\end{array}$

$\begin{array}{llll}0.1518 & 3.5 & 10.0 & 0.913\end{array}$

$\begin{array}{llll}0.1781 & 4.0 & 9.0 & 0.962\end{array}$




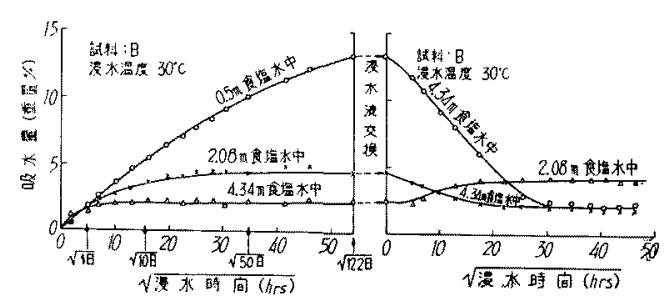

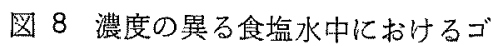
么加硫物の吸水及び脱水

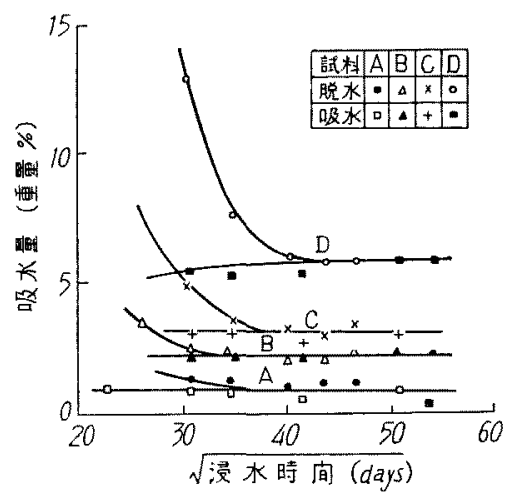

図9吸水及び脱水による飽和状態

た食塩水濃度の大きくなる之共に隇少する。

蒸溜水中あるいは㮁食塩水中で吸水した試料を，濃食 塩水中に入れ換えた場合は，図 7 および図8亿示したよ うに脱水を始め, 新しい浸漬液濃度に依存する固有な飽 和平衡值に達する。

図 7 は，蒸溜水中で 122 日間吸水した $\mathrm{A} ， \mathrm{~B} ， \mathrm{C}$ ，书 よび $\mathrm{D}$ 各試料を $4.34 m$ の食塩水溶液中に入れ換えた場 合の, 脱水状態示す。吸水した各ゴム試料は，食塩水 中では脱水を始めて一定飽和値に落着く。この飽和値は 図9に示すように，末吸水試料を4. $34 \mathrm{~m}$ の食塩水中に浸 清した場合の飽和值と一致する。

図 8 は, 各理濃度の食塩水中で吸水した B 試料を, 澧 度の異なった食塩水中に買なった食塩水中に入れ換えた 場合の，吸水および脱水の状態を示す．この場合もそれ ぞれの浸清液濃度に固有な飽和平衡值に達する。

これらの実験結果から，浸漬中におけるゴムと浸漬液 間の電解質の出入は無視できる程度に小さく，ゴムは電 解質に刘して半透膜上しての充分な特性を保持している ことがわかる，また，浸清中（約 200日）における材質 的な变化（老化なよ゙）やクリープ現象む無視できる程度 に小さい.

また，図 7 に吸水曲線と脱水曲線の直線部分の延長を
破線で示したが，この2つの延長線と溶液交換時を示す 就軸之の交点は，ほぼ一致するので，吸水量が直線関係 からはずれて過大となるのは，ゴム材犋の分化による22 3)ものでなく，吸水膨潤化伴なう表面皘の増加に基づく ものと推定される，すなわち，ゴムの吸水速度は，第 1 報の(1)式（Fick の拡散法則の簡略式の一部）に準じてい ると推定さ机る。

\section{2 吸水の温度特性}

$\mathrm{NaCl}$ を配合した $\mathrm{E}$ 試料について，吸水状態の温度特 性を $25 \sim 70^{\circ} \mathrm{C}$ の籁围で実測した結果の数例省图 10 お び图11に示す。

図10は $2 m$ 食塩水中における25，50および $70^{\circ} \mathrm{C}$ の吸 水状態の実測結果示す。浸清温度が变ると吸水速度は 変化するが，飽和吸水量はほぼー定である。

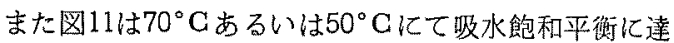
した試料の浸清温度を， $25^{\circ} \mathrm{C}$ 亿变えた場合の測定結果 である.

これらの測定結果から，飽和吸水量の温度による変化 は, 実験温度範囲内に打いては無視できる程度に小さい ことがわかる。

なお， $\mathrm{E}$ 試料の各種濃度の食垣水中における飽和吸水 量の実測值を表 2 の下部に併記した。

\section{4. 各種合成ゴムの吸水}

前節のブチルゴムについて行なったと同様な吸水実験 を，天然ゴムおよび各種の合成ゴムについて行ない，吸 水状態を観察した。

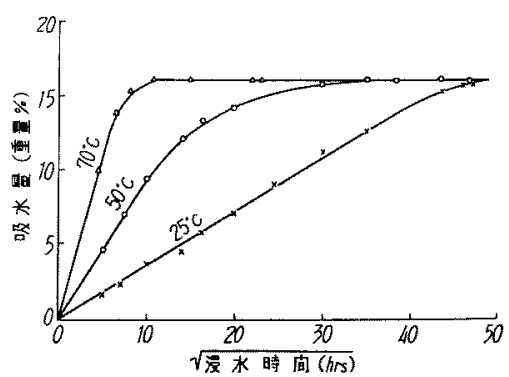

図10 $2 m$ 食塩水中に扔ける吸水

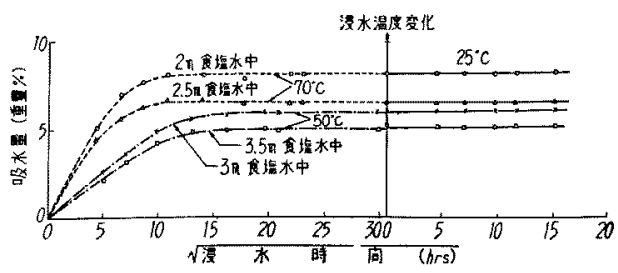

図11 飽和吸水值の温度特性 
4. 1 試料

使用したゴムは表 3 に示した 7 種類のものである。な

お，同表には灰分実測值す侀記した。

供試した基礎配合試料の配合組成は表 4 に示したが, これらの各種試料の加硫系は，それぞれの合成ゴムにつ いて一般に慣用されている采である。

クロロプレンゴムは，一般的な $\mathrm{MgO} ＼textrm{Z n O}$ を使用 した場合（試料： G R-1）上，低吸水性配合之して推奖 されている $\mathrm{PbO}$ を使用した場合 $(\mathbf{G} \mathbf{R}-2)$ との 2 種に ついて，また，SBRは凝固剤その他の処理が異なる3蹛 の銘柄（1500，1502捄よび1503）のそれぞ机の基礎配合 （SBR-1，SBR-2 およよひ SBR-3 の各試料）を供試試料 とした.
試料の調裂は常法にしたがい，オープンロール混合に よって加硫剤学配合し，表4の下段に示した条件でプレ 又加硫を行なった，試料片の厚さは0.25士0.05 $\mathrm{mm}$ であ り，直径 $30 \mathrm{~mm}$ 型に打与板いて供試した。乙の試料 片の大きさは前述のブチルゴム試料片之同様である，浸 清食塩水屯前述之同様条件で調整したものを用いた。

\section{2 吸水実験}

吸水量の測定方法は前述の場合子同様乣行ない, 試料 片を一定温度扰よび一定旡度の食塩水中に浸漬し，一定 期間浸水後の重量增加を化学天科を用いて実測し, 吸水 量とした。

吸水状態実測結果の数例老図 12 打上び図 13 亿示した が，前述のブチルゴム試料の場合之全く同様な吸水状態

表 3 供試恶么゙

\begin{tabular}{|c|c|c|c|}
\hline$コ ゙$ & 商 品 名 & $x-x-$ & 灭分旳(実測徝) \\
\hline クロロプレンゴム & ネオプレン WRT & Dupont & 0.52 \\
\hline 天 然 ゴ ム & RSS No. 2 & - & 0.41 \\
\hline スチレンブタジエンゴム & ポリサークライレン(1500相当品) & Polymer Corp. & 0.95 \\
\hline スチレンブタジエンゴム & フィルプレン 1502 & Phillips Chem. Co. & 0.79 \\
\hline スチレンブタジェンゴム & フィルプレン1503 & Phillips Chem. Co. & 0.07 \\
\hline アクリロートリルブタジエンゴム & ハイカー1041 & Goodrich Chem. Co. & 0.98 \\
\hline 椙エステルゴム & ハイカー4021 & Goodrich Chem. Co. & 0.58 \\
\hline
\end{tabular}

表 4 各種ゴムの基礎配合試料

\begin{tabular}{|c|c|c|c|c|c|c|c|c|}
\hline \multirow[b]{2}{*}{ 配 合剂 一 } & \multicolumn{2}{|c|}{$\begin{array}{c}\text { クロロプレンゴム } \\
\text { (CR) }\end{array}$} & \multirow{2}{*}{ 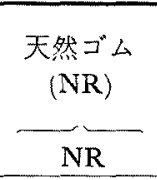 } & \multicolumn{3}{|c|}{$\begin{array}{c}\text { スチレンブタジエンゴム } \\
(\mathrm{SBR})\end{array}$} & \multirow{2}{*}{$\begin{array}{l}\text { アクリロニ } \\
\text { トリルブタ } \\
\text { シエンゴム } \\
\text { (NBR) } \\
\text { NBR }\end{array}$} & \multirow{2}{*}{ 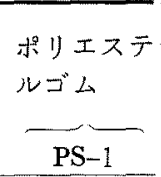 } \\
\hline & $\mathrm{CR}-1$ & $\mathrm{CR}-2$ & & SBR-1 & SBR-2 & SBR-3 & & \\
\hline （墑品名） & $\left(\begin{array}{l}\text { ネオプレ } \\
\text { WRT }\end{array}\right)$ & $\left(\begin{array}{l}\text { ネオプレ } \\
\text { ン WRT }\end{array}\right)$ & $\left(\begin{array}{l}\text { zєーク } \\
ト \neq-1 \\
\text { RSS } \neq 2\end{array}\right)$ & 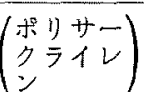 & $\left(\begin{array}{l}フ ィ ル フ ゚ ~ \\
レ ン 1502\end{array}\right)$ & $\left(\begin{array}{l}\text { フィルプ } \\
\text { レン1503 }\end{array}\right)$ & $\left(\begin{array}{c}\text { イカ一 } \\
1041\end{array}\right)$ & $\left(\begin{array}{c}\text { 1力 } \\
4021\end{array}\right)$ \\
\hline ゴ $\quad$ ム & 100 & 100 & 100 & 100 & 100 & 100 & 100 & 100 \\
\hline マグネシア & 4 & & & & & & & \\
\hline 亜 鉛 華 & 5 & & 5 & 5 & 5 & 5 & 5 & \\
\hline リ サ - シ & & 20 & & & & & & \\
\hline $\begin{array}{l}\text { エチレンチオウ } \\
\text { レア (22) }\end{array}$ & 1.2 & 1.2 & & & & & & \\
\hline 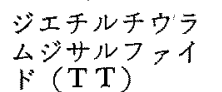 & & & 3.5 & 3.5 & 3.5 & 3.5 & 3.5 & \\
\hline 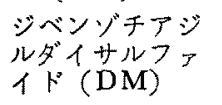 & & & 1.5 & 1.5 & 1.5 & 1.5 & 1.5 & \\
\hline $\begin{array}{l}\text { ジェチレントリ } \\
\text { アミシ }\end{array}$ & & & & & & & & 3 \\
\hline 黄 & & & & & & & & 1 \\
\hline ステアリン酸 & 2 & 2 & 2 & 2 & 2 & 2 & 2 & \\
\hline プレス加硫条件 & $150^{\circ} \mathrm{C} 30$ 分 & $150^{\circ} \mathrm{C} 30$ 分 & $150^{\circ} \mathrm{C} 20$ 分 & $150^{\circ} \mathrm{C} 30$ 分 & $150^{\circ} \mathrm{C} 30$ 伃 & $150^{\circ} \mathrm{C} 30$ 分 & $150^{\circ} \mathrm{C} 30$ 分 & $150^{\circ} \mathrm{C} 30$ 分 \\
\hline
\end{tabular}




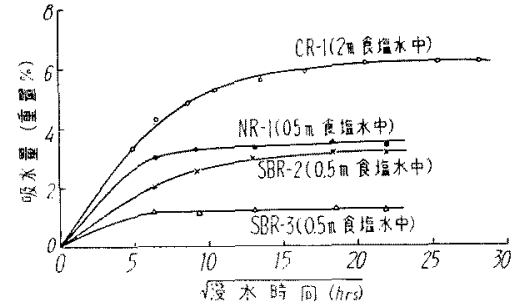

图12 各種合成ゴムの食垍水中に求ける吸水（その1）

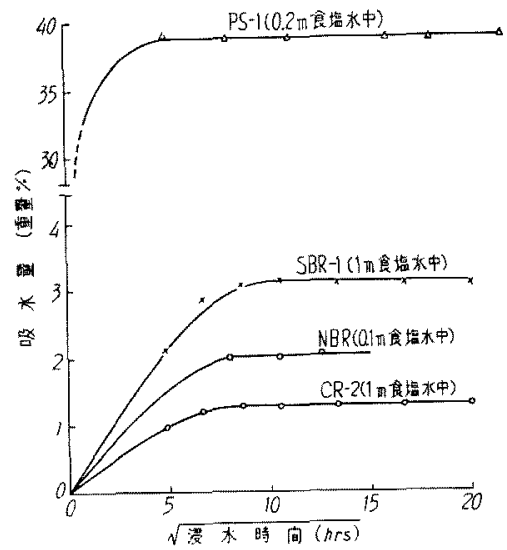

因13 各種合成ゴムの食程水中における吸水（その2）

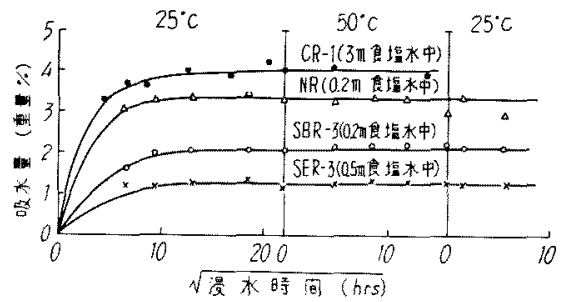

図14 飽和吸水量の温度特性

在示し，各種ゴム試料は浸漬液濃度に依存する固有な飽 和平衡值に達し，また，浸漬液濃度が增加すると吸水量 は減少する。

また，図14に例示するように，すべての供試ゴム試料 の飽和吸水量は, 温度によって変化しない。

実测した各試料の飽和吸水量を一括して表 5 に示す。

以上の上うに各牮合成ゴム基楚配合の加硫物について 得られた結果は，前述のブチルゴム加硫物について得ら れた結果上全く同様な傾向を示す.

各種合成ゴムの吸水量は，ゴム分子の親水性には特に 閣係ないように見受けられる。すな⿻ち，水は極性溶媒 なので，極性ゴムは特に吸水し易いと予想されるが，極
性度の夫きい NBR の吸水量は最す少なく， SBRー1など の非極性ゴムの吸水量がかなり多い.

3種の SBR の吸水量の相違は，電解質含有量の相違 に依存するものと推定される。このような電解算含有量 表 5 各種合成ゴ么試料の飽和吸水量

\begin{tabular}{|c|c|c|c|}
\hline 試 料 & $\begin{array}{c}\text { 漫漬食塩水 } \\
\text { 濃度: } m \\
\left(モ ル / 1 \mathrm{kgH} \mathrm{H}_{2} \mathrm{O}\right)\end{array}$ & $\begin{array}{c}\text { 部期重鼓 } \\
\mathrm{W}_{0} \\
(\mathrm{~g})\end{array}$ & $\begin{array}{c}\text { 飽和吸水量 } \\
\mathbf{Q}_{8} \\
(\%)\end{array}$ \\
\hline \multirow{4}{*}{$\mathrm{CR}-1$} & 1 & 0.2362 & 12.6 \\
\hline & 2 & 0.2427 & 6.2 \\
\hline & 3 & 0.1787 & 4. 0 \\
\hline & 4 & 0.1786 & 3.0 \\
\hline \multirow{3}{*}{ CR-2 } & 1 & 0.2435 & 1.3 \\
\hline & 0.5 & 0.2484 & 2.0 \\
\hline & 0.2 & 0.2230 & 4.2 \\
\hline \multirow{2}{*}{ NR-1 } & 0.5 & 0.1750 & 3.4 \\
\hline & 0.2 & 0.1627 & 6.9 \\
\hline \multirow{4}{*}{ SBR-1 } & 2 & 0.1890 & 3.1 \\
\hline & 1 & 0.1644 & 5.4 \\
\hline & 0.5 & 0.1742 & 10.5 \\
\hline & 0.2 & 0.1678 & 18.0 \\
\hline \multirow{4}{*}{ SBR-2 } & 1 & 0.1884 & 3.5 \\
\hline & 0.5 & 0. 1871 & 6.6 \\
\hline & 0.2 & 0.1533 & 9.8 \\
\hline & 0.1 & 0.1556 & 13. 2 \\
\hline \multirow{4}{*}{ SBR-3 } & 0.5 & 0.1639 & 1.3 \\
\hline & 0.2 & 0.1772 & 2.2 \\
\hline & 0.1 & 0.1676 & 3.0 \\
\hline & 0.05 & 0.1631 & 3.5 \\
\hline \multirow{2}{*}{ NBR-1 } & 0.2 & 0.1597 & 1.2 \\
\hline & 0.1 & 0.1517 & 2.4 \\
\hline \multirow{4}{*}{ PS-1 } & 2 & 0.1591 & 5.0 \\
\hline & 1 & 0.1790 & 10.0 \\
\hline & 0.5 & 0.1750 & 17.5 \\
\hline & 0.2 & 0.1688 & 39.0 \\
\hline
\end{tabular}

表 6 供試 SBR の製造法相異点*

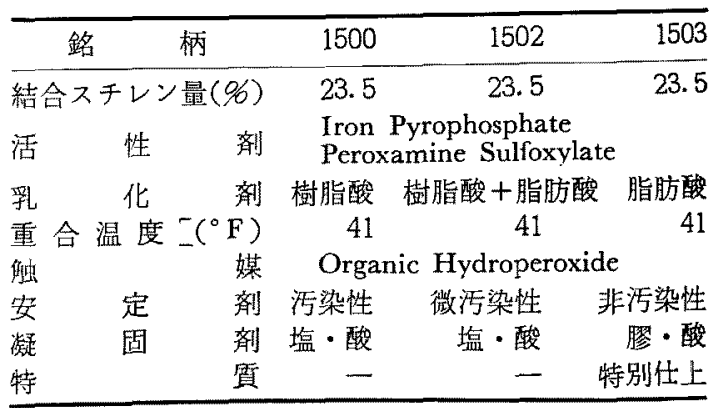

* ASTM D-1419-58T による 
の相違は製造法の相違によるものであり，供試した 3 種

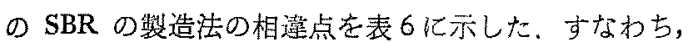
凝固剂その他の添加物化塩類を使用せず，特汇精製して 鍳解質を除いている SBR 1503 は四水量が特飞少なく, この銘柄は電気絶縁用の目的で市眅されている。な战て のような電解質含有量は表 3 亿示した灰分量によって方 る程度推定できる場合もあるが，灰分はゴム中の水溶性 物質とは異なるあのであり，灰分量でもって水溶性物質 量を正確に比校することはできない．

ポリエステルゴムの吸水量が最も多いが，これはゴム 分子側銷のエステル基の影響で，電解䫀を多量に配合し た場合と同㥞な状態になるためと推定される。実際にポ リアクリル酸，ポリメタアクリル酸などについて，ての 上うな現象が報告されている。45)

\section{5. 結訔}

本報にのべた吸水実験から得られた吸水现象の要点老 要約して個条書きに下記する。

1）吸水速度の規則性

蒸溜水中にお汀る吸水速度は，吸水量が漫水期間の 平方根に比例して吸水し続け，跑和の僋向は認められ ない，筆者の250日の寒駼，A.R. Kempの1,000 日間

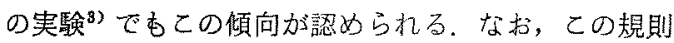
性注 Fick の拡散法則の簡略式の一部（拡散初期に求 ける拡散式）にしたがつている。 1i）吸水膨润 ゴムは吸水すると膨潤する。

iii）吸水飽和

ゴムは電解質水溶波中にては, 水溶液漕度に依存す

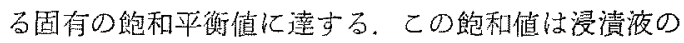
濃后汃增す之減少し, ゴム中の水溶性物質含有量が增 すと增大する，また，飽和値はゴム分子の親水性にあ まり関係しない。

iv）飽和值の温度特性

飽和吸水量は温度によって变化しない。

v) 半透膜性

ゴムは電解質に対し十分な半透膜性をすつ。

このようなゴムの吸水汇関する特買性を，熱力学を用 いて解析し，ゴムの吸水機構を追求した結果を次報に述 ベる.
文献
1）渡辺：ゴム協, 34, 594(1961)
2) 大北: ゴム協，10，538(1937)
3) A.R.Kemp : Ind. Eng. Chem., 30, 409 (1938), 29, 64 (1937)

4) W. Kuhn, B. Hargitay ; Z. Electrochem., 55, 490 (1951)

5) A.Katchalasky, S.Lifson, H.Eisenberg ; $J$. Poly Sci., 7, 571 (1951), 8, 476 (1952)

\section{THE SORPTION OF WATER BY RUBBER (Part 2)}

\section{RELATION BETWEEN CONCENTRATION OF ELECTROLYTE AND WATER ABSORPTION}

S. Watanabe (Wire \& Cable Works, Hitachi Wire \& Cable Ltd.)

The osmotic mechanism of sorption by rubber could not be shown in the Part 1 sufficiently, because, the quantitative analysis of soluble materials in rubber was impossible.

Hence, we observe the sorption by butyl rubber which contained constant weight of electrolyte. On this experiment, the saturated values of sorption are shown as a function of electrolyte concentration in rubber and in solution. By the temperature, the sorption velocity varies, but the saturated value does not vary. And the same phenomenz are recognised in the case of natural rubber and many synthetic rubber vulcanizates which do not contain fillers. 